\title{
Flippedped Learning as a Strategy to Improve Students Higher Order Thinking: (A Quasi Experiment)
}

\author{
Rani Sofya ${ }^{1(*)}$, Annur Fitri Hayati ${ }^{1}$, Rita Syofyan ${ }^{1}$ \\ ${ }^{1}$ Dep. of Economic Education, Faculty of Economy, Universitas Negeri Padang, Padang, Indonesia, \\ "Corresponding author. Email: ranisofya@fe.unp.ac.id
}

\begin{abstract}
Higher education in Indonesia needs to adjust the students' competencies with the developments that always occur to be able to succeed in 4.0 Era. The main competencies needed are critical thinking, problem solving, and Higher Order Thinking (HOT). The common learning situation, in which students learn material in class and then do assignments at home, is less able to foster the ability of HOT. Thus, a learning strategy is needed to accommodate the students' HOT. One suitable strategy for increasing HOT is Flipped Learning. Flipped Learning reverses the traditional learning process where students are provided with material in e-learning before learning in the class. The face-to-face learning process in the classroom is developed into a problem solving process, because the basic material has been mastered before they learn in the class. This was quasi experimental research. The data was analyzed by SPSS to see the effectiveness of Flipped Learning strategy in improving HOT.
\end{abstract}

\section{Keywords: Flipped learning, higher order thinking}

\section{INTRODUCTION}

Industry Revolution 4.0 Era, according to Shwab (2016), is an era which new technology developments occur by combining physical, digital and biological technologies. The 4.0 era does not only affect business sectors but also the government and education themselves, which emerges the term of Education in 4.0 Era. Dunwill (2016) states that technology developments strongly influences the methods and learning process implemented by educators. The Education Technology and Mobile Learning (2016) website advises educators to nurture 10 skills by 2020 century, namely: 1 . Overcoming complex problems, critical thinking, being creative, managing people, coordinating with others, having emotional intelligence, making judgments and decisions, being service oriented, being able to negotiate and having Cognitive Flexibility.

Universitas Negeri Padang as a provider of tertiary education whose mission is to become the leading University in Southeast Asia has sought to adapt the patterns of learning that support the growth of student selfcompetence that is linear with the 4.0 era. One of the efforts made is to provide lecture supporting facilities in the form of physical and non-physical. One of them is the provision of wi-fi facilities and www.elearningunp.ac.id site that can be accessed by lecturers and students. Through these facilities, lectures not only can carry out "real" class but also virtual one.

One of the courses taught at Universitas Negeri Padang is the Income Tax Management. The course materials are all about tax management (Pph 21, Pph 22, Pph 23, Article
4 paragraph 2, Pph 26. The discussion is quite complex so that it requires innovative ways of teaching to foster students' higher-order thinking skill which will increase student learning activities, responsibilities and independence that considerably leads to increase students' higher order thinking skills (Higher Order Thinking / HOT).

The technology used in current learning process is considerably inadequate. Thus, it is needed to use a new one called Flipped Learning strategy. Flipped learning, according to Flipped Learning Network (FLN), 2014) stands for Flexible environment, Learning culture, Intentional content, and Professional educator. The role of the instructor shifts from being a source of learning (traditional) to being a lecturer director by managing class management which includes providing access to material for students outside the classroom, and becoming a director of discussion and problem solving that is carried out in class Strayer (2007).

The teacher is an expert who will help students understand the material they are learning.

The active learning in Flipped learning allows students to apply and practice concepts and skills during class with instructors presented to provide lectures and support. Cole (2009) revealed that Flipped learning is an approach that allows students to practice and demonstrate their skills in front of the teacher without losing the scope of the material. At the same time, it can also spur life-long learning skills by requiring students to gain pre-class exposure to course content, through video lectures, so that when they arrive at class, they are definitely ready to work 
(Sofya, 2018). Active learning leads to increase involvement in one's learning, increased understanding and results, and more learning experiences, including higher level skills Bloom taxonomy (HOT). HOT is higher order thinking skills including critical, logical, reflective, metacognitive, and creative thinking (King, 2010).

Heong et all (2001) express Higher Order Thinking as broad thinking to solve a challenge. Higher Order Thinking is the highest cognitive level in Bloom's Taxonomy. In Bloom's Revised Taxonomy, there are levels of thinking as follows: knowing (C1), understanding (C2), applying (C3), analyzing (C4), evaluating (C5) and Creating (C6). Limbagh \& Waugh (2010) suggested 5 ways to develop critical thinking skills, namely determining learning goals, learning by discovery, training, reviewing, redefining to improve understanding and practicing to assess and provide feedback. The Australian Council for Educational Research reveales that the ability to think at a higher level is the process of analyzing, reflecting, giving arguments, applying concepts to a different situation, composing and creating.

Based on the background stated above, the authors are interested in conducting a Flipped Elearning strategy study to improve Higher Order Thinking Students in 4.0 Era.

\section{METHOD}

This research was an experimental research. The design of this study uses Nonequivalent Pretest-Post Test Control Group Design which is a type of quasiexperimental research. This research was conducted in the experimental group and the control group selected through purposive sampling. The experimental class taken was a class section of 201912330030 (37 students) and the control class taken was a class section of 201912330037 (36 students).

Testing Basic Assumptions

The normality test results showed populations are normally distributed. The results of the normality test populations that are homogeneous.

\section{RESULTS AND DISCUSSION}

Table 1. Paired Samples Test for Higher Order Thinking of Experimental Class

\begin{tabular}{|c|c|c|c|c|c|c|c|c|c|}
\hline \multicolumn{10}{|c|}{ Paired Samples Test } \\
\hline & & \multicolumn{5}{|c|}{ Paired Differences } & \multirow{5}{*}{$\mathrm{T}$} & \multirow{5}{*}{$\begin{array}{l}\mathrm{d} \\
\mathrm{f}\end{array}$} & \multirow{5}{*}{$\begin{array}{l}\text { Sig. } \\
\text { (2- } \\
\text { tail } \\
\text { ed) }\end{array}$} \\
\hline & & \multirow{4}{*}{$\begin{array}{c}\mathrm{Me} \\
\text { an }\end{array}$} & \multirow{4}{*}{$\begin{array}{c}\text { Std. } \\
\text { Devia } \\
\text { tion }\end{array}$} & \multicolumn{3}{|c|}{$95 \%$} & & & \\
\hline & & & & $\begin{array}{l}\text { Std } \\
\text { Err } \\
\text { or } \\
\text { Me }\end{array}$ & $\begin{array}{l}\text { Conf } \\
\text { e Int } \\
\text { of } \\
\text { Diffe }\end{array}$ & $\begin{array}{l}\text { idenc } \\
\text { erval } \\
\text { the } \\
\text { erenc } \\
\text { sen }\end{array}$ & & & \\
\hline & & & & an & Lo & Upp & & & \\
\hline & & & & & wer & er & & & \\
\hline & Post & 37.7 & 9.083 & 1.4 & 34.6 & 40.7 & 25.2 & 3 & .00 \\
\hline $\mathrm{P}$ & Experi & 03 & & 93 & 74 & 31 & 50 & 6 & 0 \\
\hline ai & ment - & & & & & & & & \\
\hline $\mathrm{r}$ & Pretest & & & & & & & & \\
\hline 1 & Experi & & & & & & & & \\
\hline & ment & & & & & & & & \\
\hline
\end{tabular}

Table 1 shows the results of processed data using SPSS version 21.0. Table 1 showed that $\mathrm{t}_{\text {obtained }}=25.250$ $(\mathrm{df}=36)$, $\mathrm{p}$-value $(2$-tailed $)=0,000$ which is much smaller than 0.05 . The test results are very significant, so that Ho was rejected. The average of students' higher order thinking skills after learning to use Flipped Learning Strategy is higher than before. It can be concluded that there are significant differences in students' Higher Order Thinking before and after learning by using the Flipped Learning Strategy in the experimental class.

Based on the results of the calculation of the pretest and post test scores, the average value of the Higher order thinking of the experimental class was obtained $n$ tabulated in table 2 .

Table 2. N-Gain Higher order thinking Experiment Class

\begin{tabular}{|c|c|c|c|c|c|}
\hline Data & $\begin{array}{c}\text { Avera } \\
\text { ge } \\
\text { Score }\end{array}$ & $\begin{array}{c}\text { Improvem } \\
\text { ent }\end{array}$ & $\begin{array}{c}\text { N- } \\
\text { Gai } \\
\text { n }\end{array}$ & $\begin{array}{c}\text { N- } \\
\text { Gai } \\
\text { n } \\
\text { Ind } \\
\text { ex }\end{array}$ & $\begin{array}{c}\text { Interpreta } \\
\text { tion }\end{array}$ \\
\hline $\begin{array}{c}\text { Prete } \\
\text { st }\end{array}$ & 41,89 & & & $\begin{array}{l}\mathrm{g}> \\
0,70 \\
0,30\end{array}$ & $\begin{array}{l}\text { High } \\
\text { Moderate } \\
\text { Low }\end{array}$ \\
\hline $\begin{array}{c}\text { Post } \\
\text { test }\end{array}$ & 79,59 & 37,70 & $\begin{array}{c}0,64 \\
7\end{array}$ & $\begin{array}{c}<\mathrm{g} \\
< \\
0,70 \\
\mathrm{~g} \leq \\
0,30\end{array}$ & \\
\hline
\end{tabular}

Table 2 provides information that there was an increase in Higher order thinking between before and after using the Flipped Learning Strategy in the experimental class which was amounted to 0.647 . When compared with a gain index of $0.30<\mathrm{g}<0.70$, the increase in Higher order thinking is categorized as moderate. Based on the N-Gain Higher order thinking experimental class, it can be concluded that there are differences in Higher order thinking Students before and after using the Flipped Learning Strategy in the experimental class which is categorized as moderate.

The results of this study are in line with Wilson (2013) and Gaughan (2014). They state that the implementation of Flipped learning is able to improve student learning outcomes. Earle (2016) also expressed his success in carrying out Flipped learning in the quantitative methodology class he taught. The Maolidah study (2017) found that the application of the Flippedped Classroom learning model is effectively used to improve students' critical thinking skills, which is critical thinking is one of the Higher Order Thinking.

The implementation of Flipped Learning not only enhances Higher Order Thinking in learning, but in the learning process there is a process of interaction between students and educators and the learning environment that is expected to produce a change in behavior. When educators apply Flipped Classroom, teachers become more interactive with students and are able to create a variety of conditions and situations in learning both at home and in 
class so that goals are achieved, both learning outcomes and thinking abilities (cognitive, affective, and psychomotor). The implementation of Flipped learning has also succeeded in providing active learning experiences for students, as revealed by Butt (2014). Braun, Ritter, and Vasko (2014) show that with Flipped learning students have freedom and independence in carrying out learning outside the classroom.

Not only oriented towards learning outcomes or achievements, but by using Flipped Learning students have skills in technology, media, and information, critical thinking skills, communication skills, collaboration, creative, and innovative (Learning and innovation skills), knowledge and expertise that are relevant to the learning framework of the 21 st century.

To see how much influence the Flipped Learning Strategy has on students' Higher Order Thinking improvement is known by calculating the effect size. Calculation of effect size in N-Gain data of experimental and control class using SPSS version 21, while the results are in table 3 .

Table 3. Anova and Eta Test Results

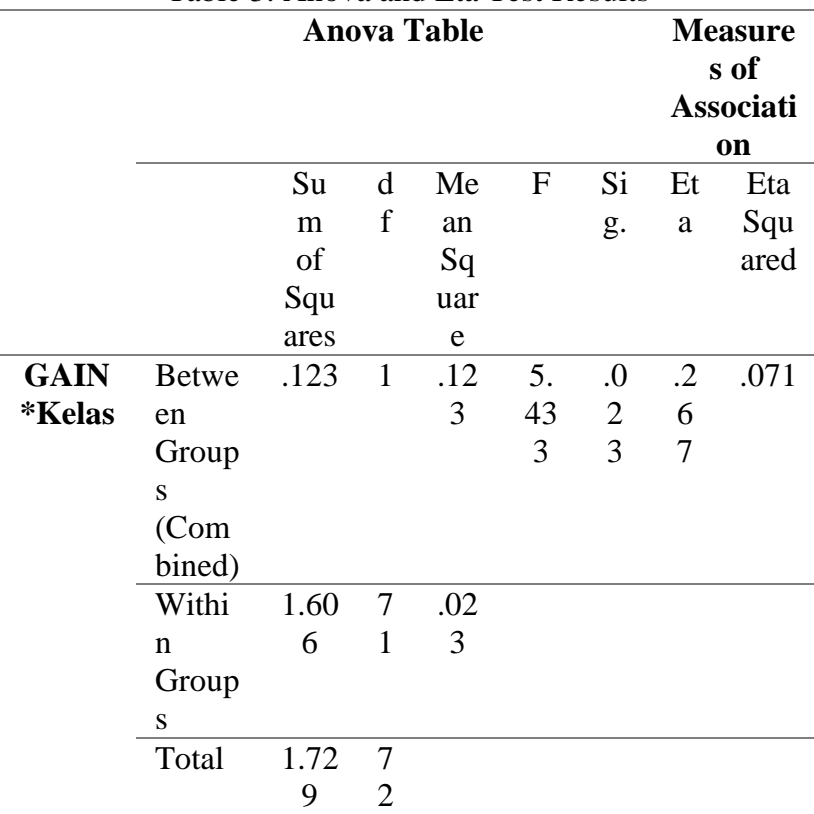

Based on table 8 , the table's $\mathrm{F}$ value $=5.433$ and $\mathrm{p}$ value $($ Sig. $)=0.023$ less than 0.05 , which means that the treatment of Flipped Learning Strategy is very significant in affecting Gain. The effect of the Flipped Learning Strategy treatment on the increase in Higher Order Thinking of students in the amount of 0.071 (eta squared $(n 2)=0.071)$ included in the small category $(0.071 \leq$ 0.10 ), meaning that the variability of students' Higher Order Thinking increased by $7.1 \%$ by through Flipped Learning Strategy and the remaining $92.9 \%$ are influenced by other factors.

\section{CONCLUSIONS}

The conclusion of the research is there is different increase of students' Higher Order Thinking skill who treated by
Flipped Learning and those who used conventional strategies. The difference in improvement is seen from the acquisition of posttest score gain. This means that the use of the Flipped Learning Strategy can improve Higher Order Thinking better than conventional strategies. The magnitude of the influence of the Flipped Learning Strategy on Higher Order Thinking is included in the small effect.

\section{REFERENCES}

[1] Braun, I., Ritter, S., \& Vasko, M. (2014). Inverted classroom by topic - A study in mathematics for electrical engineering students. International Journal of Engineering Pedagogy, 4(3), 11-17.

[2] Butt, A. (2014). Student views on the use of a Flippedped classroom approach: Evidence from Australia. Business Education \& Accreditation, 6, $33-43$.

[3] Cole, J. E., \& Kritzer, J. B. (2009). Strategies for success: Teaching an online course. Rural Special Education Quarterly, 28(4), 36-40.

[4] Critz, C. M., \& Knight, D. (2013). Using the Flippedped classroom in graduate nursing education. Nurse Educator, 38, 210-213.

[5] Dunwill, E (2016). 4 Changes that will be shape the classroom of the future: Making education fully technological. Accesed from: https://elearningindustry.com/4- changes-willshape-classroom-of-the-future-making-educationfully-technological.

[6] Earle, Mark. (2016) Flippedping the Graduate Qualitative Research Methods Classroom: Did It Lead to Flippedped Learning? International Journal of Teaching and Learning in Higher Education, Volume 28, Number 1, 139-147

[7] Education technology and Mobile Learning (2016). 9 Fundamental digitall skills For 21st century Teachers. Accesed from : https://www.educatorstechnology.com/2016/12/9fundamental-digital-skills-For $21 \mathrm{sthtml}$

[8] Fisk, P. (2017) Education 4.0...the Future Of learning will dramatically different, in School and Troughout Life. Retrieved From: http://wwwthegeniuswork.com/2017/01/futureeducation-young-everyone-taughttogether.

[9] Gaughan, J. E. (2014). The Flippedped classroom in world history. The History Teacher, 47, 221 244

[10] Gaughan, J. E. (2014). The Flippedped classroom in world history. The History Teacher, 47, 221 244

[11]Heong, Y.M, Othman, W.D.,Md Yunos, J., Kiong, T.T, Hassan, R., \&Mohamad, MM. ( 2001). The Level Of Marzano Hihger Order Thinking SkillAmong Technical Education Students. International Journal Of Social and Humanity, Vol 1,No 2, July 2011, 121-125 
[12] Limbagh, B \&Waugh W. (2010). Developing Higher Order Thinking. Journal of Instructional Pedagogis: 1-9

[13] Maolidah, I. S., Ruhimat, T., \& Dewi, L. (2017). Efektivitas Penerapan Model Pembelajaran Flippedped Classroom pada Peningkatan Kemampuan Berpikir Kritis Siswa. Educational Technologia, 3(2).

[14] Shwab, K. (2016) The Fourt Industrial Revolution: what it means, how to respond. Accesed from https://www.weforuum.org/agenda/2016/01/the-

fourt-industrialndustrial- revolution-what-itmeans-how-to-respond

[15] Sofya, R. (2018). Implementasi Flipped Learning Strategi Meningkatkan Higher Order Thinking Mahasiswa. Jurnal Inovasi Pendidikan Ekonomi, 8(1), 39-48.

[16] Strayer, J. F. (2007). The effects of the classroom Flipped on the learning environment: A comparison of learning activity in a traditional classroom and Flipped classroom that used an intelligent tutoring system (Doctoral dissertation). Ohio State University Retrievedfromhttp://etd.ohiolink.edu/view.cgi?acc _num=osu1189523914.

[17] Wilson, S. G. (2013). The Flippedped class: A method to address the challenges of an undergraduate statistics course. Teaching of Psychology, 40, 193- 199 